\title{
Penerapan Metode MVC Framework Code Igniter untuk Sistem Informasi Administrasi Transaksi E-Commerce Perusahaan Aktualita
}

\author{
Sunarto Usna ${ }^{1}$, Andri Yanto ${ }^{2}$, dan Soegijanto ${ }^{3}$ \\ 1,2,3 Sistem Informasi, STMIK Jakarta STI\&K, Jl. BRI Radio Dalam, Kebayoran Baru, Jakarta \\ e-mail: ${ }^{1}$ sunartousna@gmail.com, ${ }^{1}$ andri_yanto@gmail.com, ${ }^{1}$ soegijanto@jak-stik.ac.id \\ Submitted Date: February $26^{\text {th }}, 2021$ \\ Revised Date: June $04^{\text {th }}, 2021$ \\ Reviewed Date: June 02 $2^{\text {nd }}, 2021$ \\ Accepted Date: June $15^{\text {th }}, 2021$
}

\begin{abstract}
Aktualita is one of the business activities engaged in the sale of stationery and printing located in South Jakarta. Activities related to promotions, data collection of goods, processing carried out do not yet have a standard database. Data processing takes a long time to produce information. The processing process contains errors in recording inaccurate data. Based on this information, the researchers tried to make a solution to these problems by creating a system in the form of a website using the CodeIgniter Framework. This research activity intends to find a solution with an administrative system for managing sales of goods transactions. The system built in this study uses a codeigniter framework. Making sales applications can be a solution to help make it easier for companies to actually manage goods data. Good data processing can make it easier to generate reports more quickly and accurately.
\end{abstract}

Keywords: System; Information; MVC; Framework; Codeigniter; MySql

\section{Abstrak}

Aktualita adalah salah satu kegiatan usaha yang bergerak di bidang penjualan alat tulis dan percetakan yang berlokasi di Jakarta Selatan. Kegiatan terkait promosi, pendataan barang, pengolahan yang dilakukan belum memiliki database standar. Pengolahan data membutuhkan waktu yang lama untuk menghasilkan informasi. Proses pengolahan tersebut mengandung kesalahan dalam pencatatan data yang tidak akurat. Berdasarkan informasi tersebut maka peneliti berusaha membuat solusi permasalahan tersebut dengan membuat sistem dalam bentuk website dengan menggunkan Framework CodeIgniter. Kegiatan penelitian ini bermaksud untuk mencari solusi dengan sistem administrasi pengelolaan transaksi penjualan barang. Sistem yang dibangun pada penelitian ini menggunakan framework codeigniter. Pembuatan aplikasi penjualan dapat menjadi solusi untuk membantu mempermudah perusahaan sebenarnya dalam mengelola data barang. Pengolahan data barang yang baik dapat memudahkan dalam menghasilkan laporan dengan lebih cepat dan akurat.

\section{Kata Kunci: Sistem; Informasi; MVC; Framework; Codeigniter; Mysql}

\section{Pendahuluan}

Perkembangan teknologi khususnya teknologi informasi sangat berperan membantu semua kegiatan kita sehari-hari. Hampir semua kegiatan semakin tergantung dengan teknologi infomrasi ini karena jumlah dan kompleksitas data semakin banyak. Kemajuan teknologi informasi ini terus memasuki semua kegiatan kehidupan kita seperti bidang pendidikan, penjualan, transportasi, perbankan dan lainnya. Ini merupakan bukti bahwa kehidupan manusia semakin tergantung terhadap teknologi informasi ini.
Dunia bisnis yang persaingannya begitu ketat secara global wajib menggunakan teknologi informasi. Kecepatan dan keakuratan data menjadi tolak ukur kegiatan bisnis ini memilki kualitas atau tidak untuk dapat bersaing dengan kompetotor yang lain. Perusahaan Aktualita merupakan perusahaan bidang penjualan dan percetakan khususnya untuk kebutuhan peralatan perkantoran atau bisa disingkat ATK. Perusahaan ini dalam pemanfaatan teknologi informasi masih sedikit. Proses bisnis yang dilakukan masih belum menggunakan database sebagai media pencatatan 
data. Pengolahan dan penyimpanan data transaksi bisnis belum terstruktur menggunakan database. Begitu juga dalam pelaporan transaksi masih menggunakan pencatatan buku.

Proses pencatatan seperti ini sangat tidak efektif karena membuang waktu banyak dan tenaga serta biaya. Penelitian berdasarkan gambaran masalah yang sudah dijelaskan peneliti membangun sebuah sistem informasi. Penelitian ini mencoba menjawab permasalahan pada perusahaan Aktualita pada proses pengolahan data transaksi penjualan dan pengolahan data digudang. Sistem yang dibangun dapat membantu perusahaan Aktualita dalam mengolah data-data informasi perusahaan menjadi lebih cepat, tepat dan akurat. Sistem ini dapat meminimalisir dan mengurangi kesalahan dan biaya serta waktu.

\section{Metode Penelitian}

Perusahaan Aktualita merupakan perusahaan yang bergerak dibidang penjualan ATK dan percetakan yang didirikan pada tahun 2010 an oleh bapak Riyanto. Lokasi perusahaan beralamat di Jalan Bangka I D No. 1 Pela Mampang, Mampang Prapatan, Jakarta Selatan.

Perusahaan Aktualita memiliki struktur organisasi berbentuk garis. Semua bagian dari perusahaan tersebut memiliki tugas dan tanggung jawab kepada atasnya. Struktur organisasi ini menggambarkan tugas pengawasan, pengendalian dan perencanaan berbeda sesuai garis kewenangan antara pimpinan kepada bawahan.

Pada Gambar 1 dijelaskan Perusahaan Aktualita pemilik memimpin langsung kegiatan bisnis. Karyawan-karyanan bertugas pimpinan membantu sesuai tugas dan tanggung jawab masing-masing.

Pemimpin perusahaan bertugas memimpin pelaksana usahan ternasuk melakukan perencanaan, pengawasan dan pengevaluasi. Bagian Kasir bertugas mencatat dan menerima transaksi penjualan barang kepada konsumen.
Kasir juga harus memberikan pelayanan yang baik kepada siplier, relasi perusahaan dan media. Bagian gudang bertugas untuk melayani pelanggan. Pelayanan yang harus diberikan secara maksimal. Bagian gudang juga harus bekerjasama dengan bagian lain agar tidak terjadi kesalahan terhadap kondisi barang.

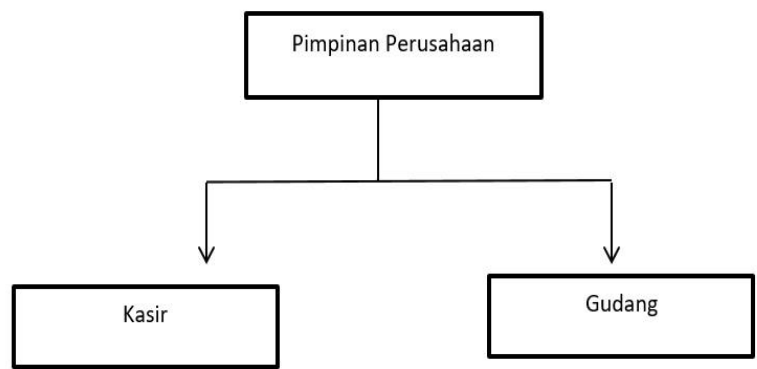

Gambar 1. Struktur Organisasi Perusahaan Aktualita

Proses pengelolaan data pada Perusahaan Aktualita menggunakan pencatatan secara berkas. Jika terjadi transaksi dalam jumlah besar akan menimbulkan kewalahan proses pendataan. Transaksi terjadi seperti terjadinya data barang masuk atau barang keluar yang tentunya jumlah data harus benar dalam selisih.

\section{Struktur Navigasi}

Pada tahap ini terdapat struktur navigasi dari aplikasi penjualan. Struktur navigasi yang digunakan adalah struktur navigasi campuran, struktur navigasi campuran adalah gabungan dari ketiga struktur sebelumnya yaitu linier, non-linier dan hirarki. Struktur navigasi ini banyak digunakan dalam tahap pembuatan website karena struktur ini memberikan relasi antar halaman yang lebih baik dikarenakan pembuatan website ini secara terstruktur. Berikut di bawah ini adalah struktur navigasi sistem.

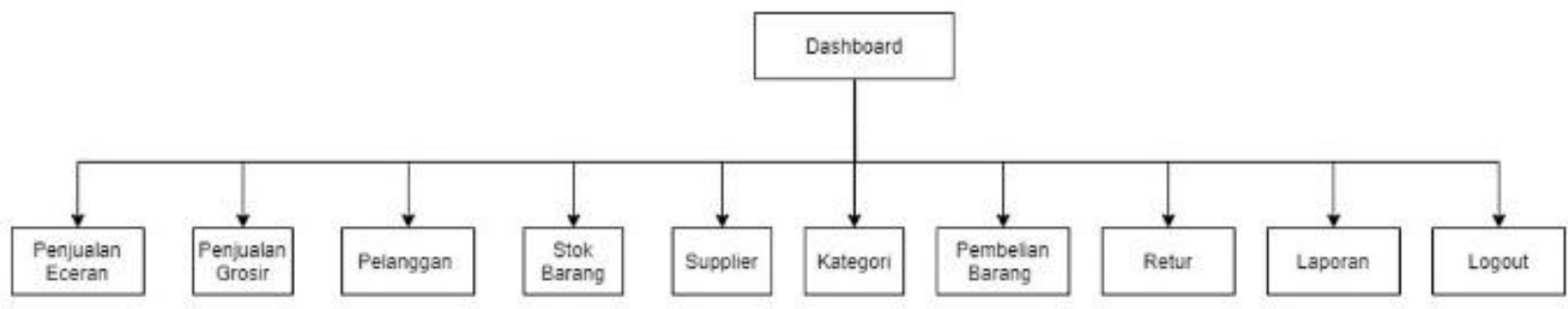

Gambar 2. Struktur Navigasi Sistem 


\section{Perancangan Sistem}

Model yang digunakan untuk merancang aplikasi penjualan berbasis website ini adalah Unified Modeling Language (UML). UML digunakan untuk mempermudah dalam memahami rancangan sebuah sistem.

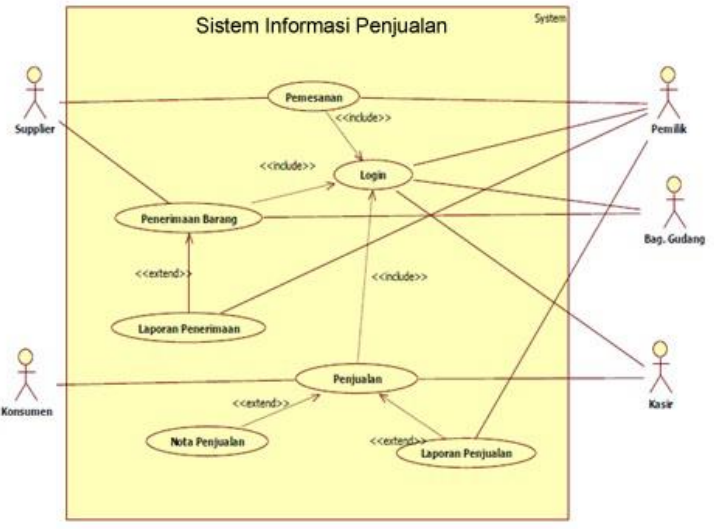

Gambar 3 Diagram Usecase Sistem

Pada Gambar 3 dijelaskan pengguna dan interaksinya dengan sistem. Admininistrator dapat melakukan proses pembelian barang ke supplier. Suplier Pihak yang dapat melakukan proses pembelian barang ke supplier. Bagian Gudang menerima barang dari supplier dan mengecek kondisi barang. Bagian Kasir melayani kebutuhan konsumen. Pelanggan yang membeli barang di perusahaan

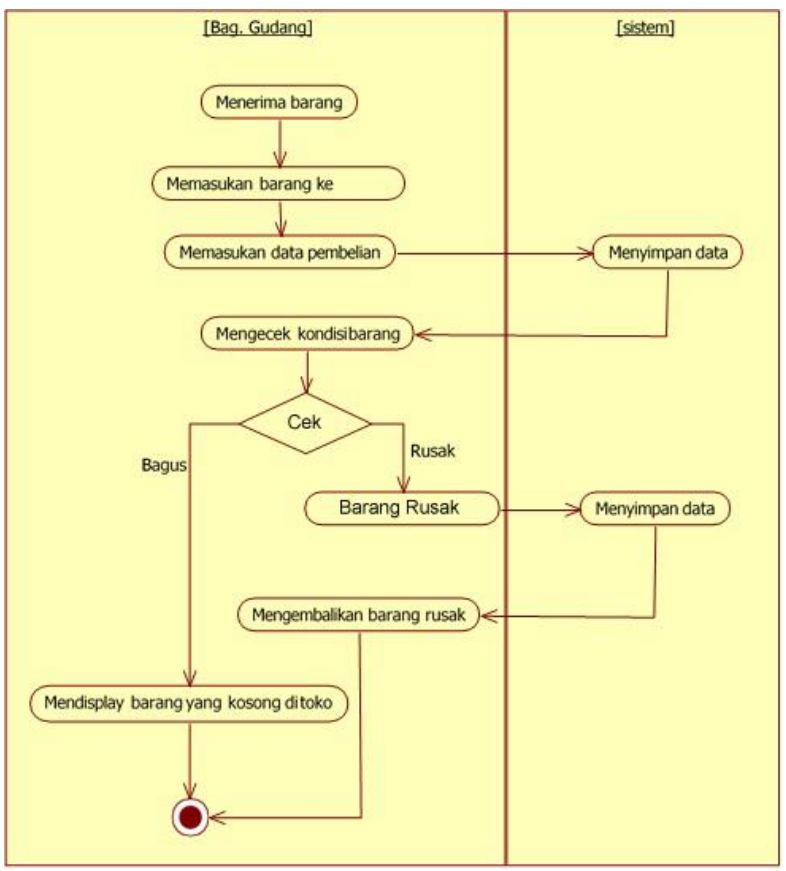

Gambar 4. Diagram Aktivitas Gudang
Gambar 4 menjelaskan aktivitas yang ada pada bagian gudang. Bagian gudang ini menampung dan mengeluarkan barang untuk dijual kepada pelanggan dan mengirim laporan kepada pimpinan stok barang yang masih tersedia. Jika stok barang tidak cukup maka dilakukan pemesanan dan pembelian kepada supplier.

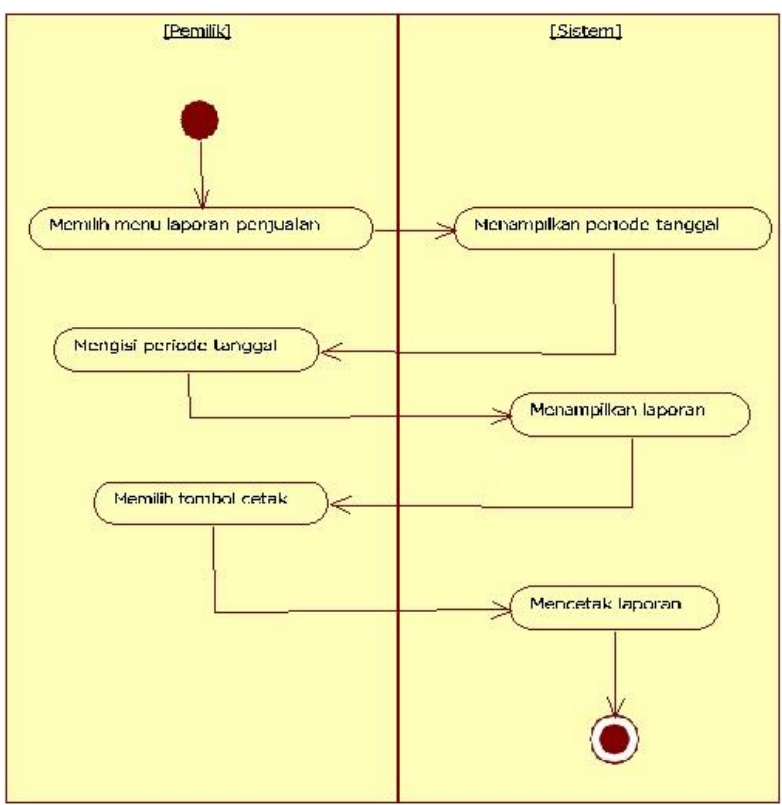

Gambar 6. Diagram Aktivitas Kegiatan Penjualan Barang

Pada Gambar 6 dijelaskan tentang laporan transaksi penjualan barang. Laporan transaksi penjualan barang ini dapat dilakukan secara spesifik bisa berdasarkan tanggal transaksi atau berdasarkan data barang.

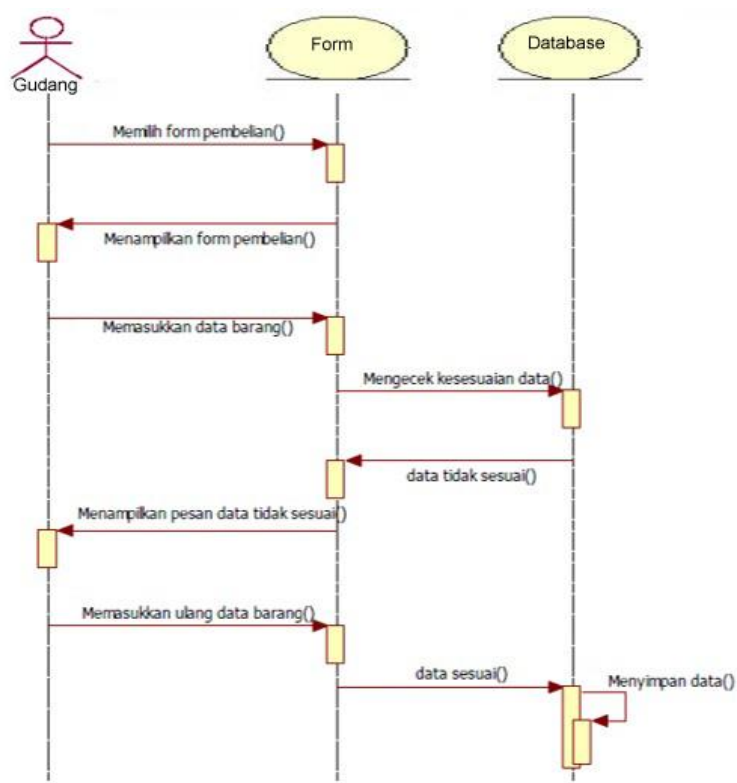

Gambar 7. Diagram Sequence Penerimaan Barang 
Gambar 7 menjelaskan urutan langkah proses penerimaan barang pada bagian gudang. Diagram ini menggambarkan aktifitas pada halaman sistem informasi bagian gudang.

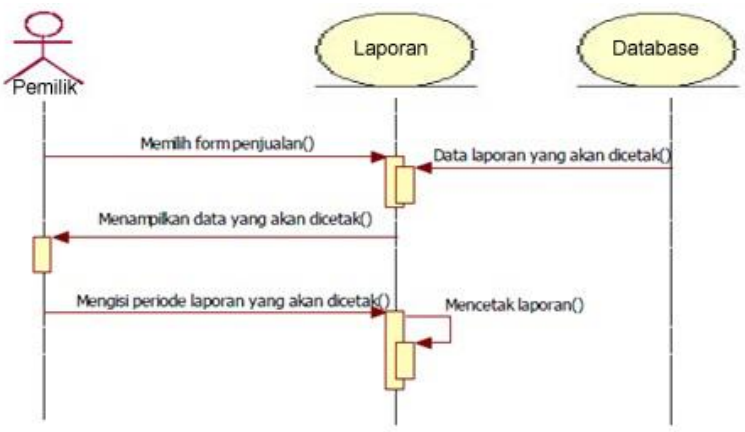

Gambar 8. Diagram Sequence Laporan Transaksi Penjualan

Gambar 8 dijelaskan urutan langkah proses laporan transaksi penjualan barang. Diagram ini menggambarkan aktifitas pada halaman sistem informasi untuk pemilik perusahaan.

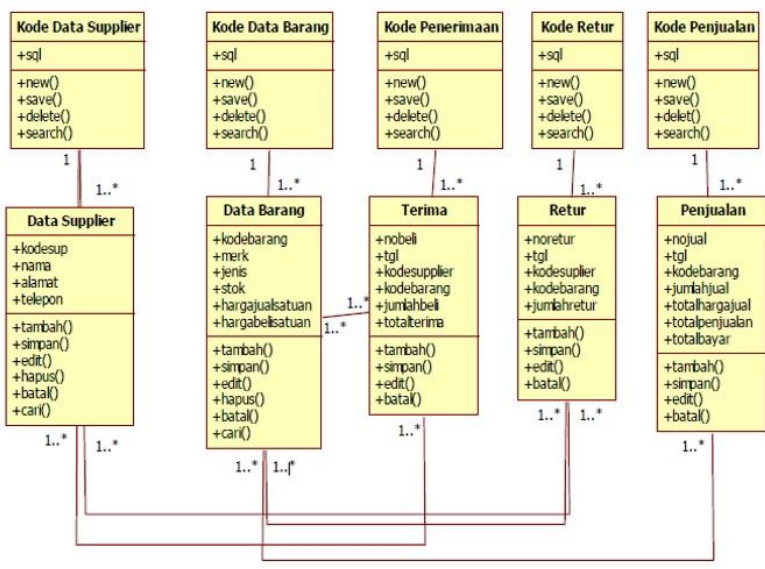

Gambar 9. Diagram Kelas Sistem

Diagram Kelas seperti pada gambar 9 menjelaskan hasil dari rancangan elemen-elemen yang akan disimpan dalam bentuk database. Kelaskelas tersebut memiliki atribut masing-masing yang berbeda. Setiap kelas memiliki fungsi dan metode pembacaan data berbeda.

\section{Perancangan Sistem}

Berikut ini adalah hasil tahapan pengembangan sistem dari mulai analisa, perancangan, desain dan pengkodean program menggunakan metode MVC Framework Codeigniter. Tampilan halaman sistem sebagai berikut:

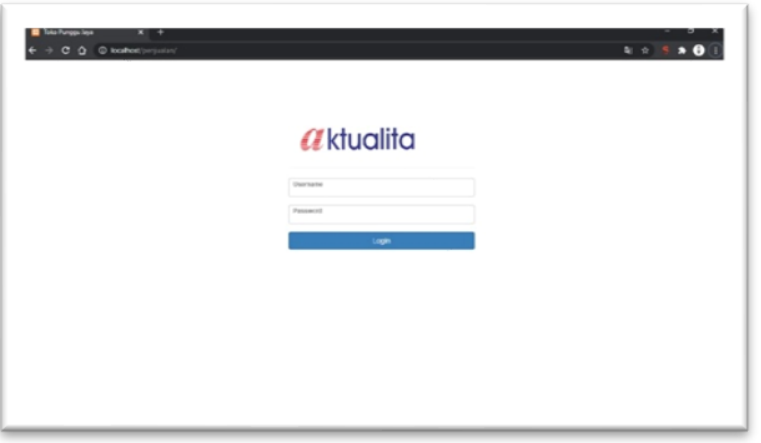

Gambar 10. Halaman Login Sistem

Untuk mengakses sistem pengguna harus memiliki hak akses berupa akun. Akun sistem memiliki kerahasiaan berupa username dan password.

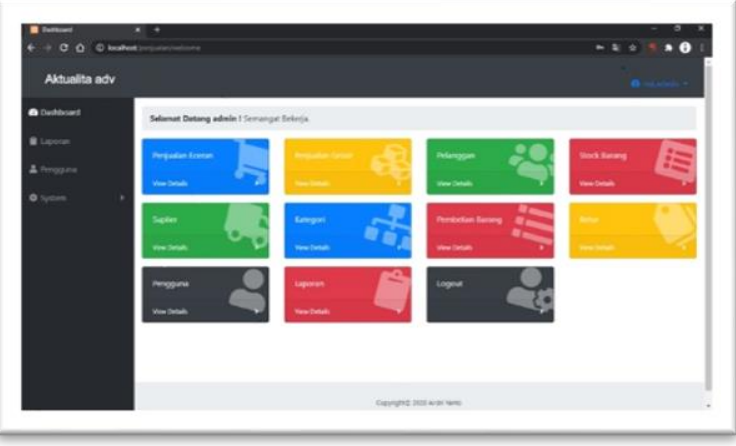

Gambar 11. Halaman Administrator.

Pada halaman administrator seperti pada gambar 11. Berisi semua menu sesuai kebutuhan sistem. Hanya bagian administrator yang dapat mengakses semua menu. Pengguna lain hanya bisa mengakses menu sesuai dengan bagiannya.

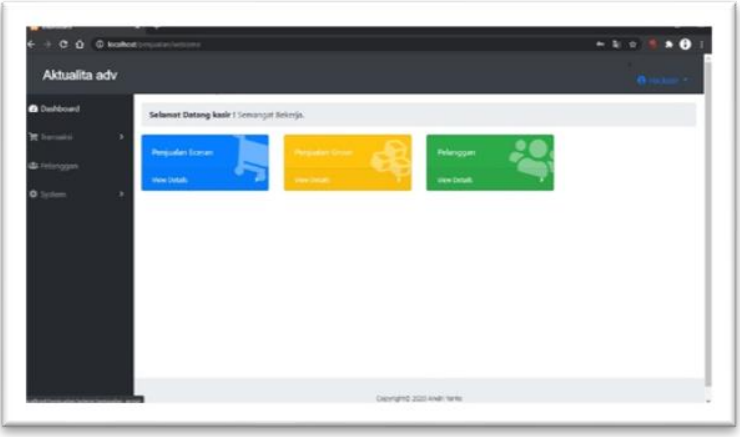

Gambar 12. Halaman Kasir

Pada gambar 12 adalah halaman yang hanya bisa di akses oleh bagian kasir. Halaman ini berisi semua transaksi penjualan barang keluar. Semua 
transaksi penjualan barang akan tercatat secara detail.

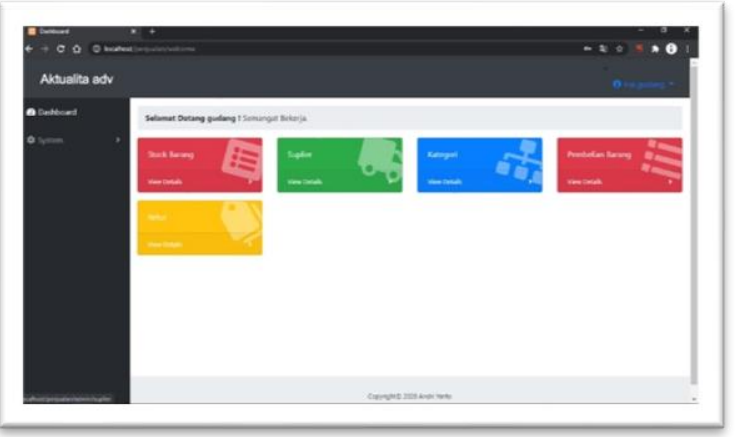

Gambar 13. Halaman Bagian Gudang.

Pada Gambar 13 adalah halaman yang bisa dilakukan oleh bagian gudang. Bagian gudang akan melakukan transaksi pemasukan dan pengeluaran barang. Bagian ini perlu mencatat stok barang apakah masih cukup atau perlu dilakukan pemesanan dan pembelian barang.

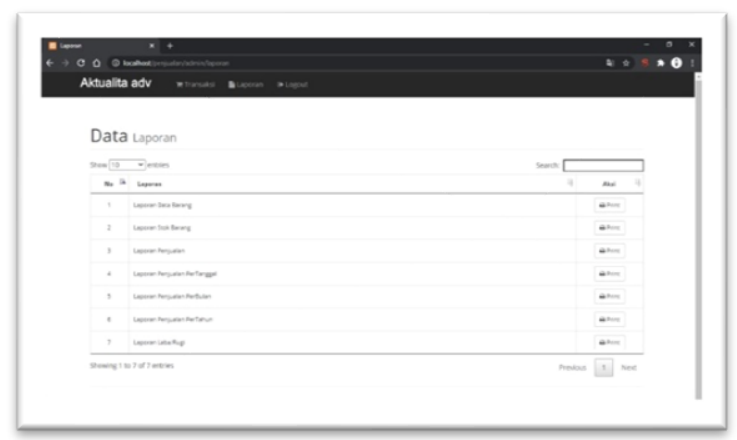

Gambar 14. Halaman Laporan Transaksi.

Pada halaman ini dapat dilakukan pembuatan laporan transaksi pembelian barang untuk stok gudang dan laporan penjualab barang oleh konsumen. Seperti pada gambar 14 fasilitas pembuatan laporan dapat dilakukan secara detail. Laporan bisa dibuat sesuai tanggal, sesuai produk atau sesuai transaksi.

\section{Kesimpulan}

Hasil peneltian yang secara detail sudah digambarkan bahwa sistem informasi ini sangat dibutuhkan oleh perusahaan Aktualita. Sistem yang dibangun menggunakan model MVC Framework Codeigniter sangat memberikan manfaat. Hasil pengujian program ini dapat disimpulkan dengan penjelasan sebagai berikut: a. Sistem dapat membantu bagian gudang dalam mengelola data barang masuk, barang keluar, stok barang dan pengembalian barang.

b. Sistem dapat membantu proses pemesanan barang jika stok sudah tidak cukup sehingga kekosongan barang tidak akan terjadi. Konsumen dapat membeli barang sesuai kebutuhan saat itu juga.

c. Proses pembuatan laporan menjadi lebih mudah karena secara langsung dapat di cetak dengan data yang akurat. Proses pembuatan laporan ini dapat dibuat secara spesifik baik berdasarkan waktu atau data item barang.

\section{Referensi}

Abdul, K. (2010). Belajar Database Menggunakan MySQL, penerbit ANDI, Yogyakarta, 2010. Jogjakarta: Andi Offset.

Daqiqil, I. (2011, 03 22). Framework Codeigniter Sebuah Panduan Dan Best Practice. Retrieved from Panduan Framework Codeigniter: www.koder.web.id

Dharwiyanti, S. d. (2013, 03 13). Pengantar Unified Modeling Language. Retrieved from ilmukomputer: ilmukomputer.com

Kotler, P. (2008). Manajemen Pemasaran. Jakarta: Erlangga.

Nugroho, B. (2008). Aplikasi Pemrograman Web Dinamis Dengan PHP dan MySQL. Yogjayakrta: Gaya Media.

Raharjo Budi, I. H. (2010). Pemrograman Web (HTML, $P H P, \& M y Q L$ ). Bandung: Modula.

Rendytama, J. (2013). Pembuatan Aplikasi Pengelolaan Transaksi Kendaraan Bermotor di Suzuki Panorama Ngawi Menggunakan Framework CodeIgniter. Surakarta.: Universitas Muhammadiyah.

Riyanto. (2011). Membuat Aplikasi E-Commerce dengan $P H P$ \& MySQL menggunakan CodeIgniter \& Jquery. Yogyakarta: CV Andi Offset.

Santoso, H. (2010). Membangun Aplikasi Web. Jakarta: Elex Media Komputindo.

Winardi. (1982, 02 03). Kamus Ekonomi. Alumni, p. hal. 97. 